Check for updates

Cite this: RSC Adv., 2018, 8, 7164

Received 21st December 2017 Accepted 7th February 2018

DOI: 10.1039/c7ra13547e

rsc.li/rsc-advances

\title{
Aromatic alkyne insertion into six-membered cyclometalated pyridine complexes of iridium: different insertion modes and structurally novel products $\dagger$
}

\author{
Xiaodan Chu, Shaowei Zhang, Zhuo Wang, Tongyu Li and Bolin Zhu (D)*
}

\begin{abstract}
Reactions of 2-benzoylpyridine or 2-benzylpyridine with $\left[C p * \mathrm{MCl}_{2}\right]_{2}(\mathrm{M}=\mathrm{Ir}$, Rh) have been carried out in the presence of $\mathrm{NaOAc}$ in refluxing methanol, which form the corresponding six-membered cyclometalated products (1-3) except for the reaction of 2-benzylpyridine with $\left[\mathrm{Cp}^{*} \mathrm{RhCl}_{2}\right]_{2}$. Insertion reactions of two six-membered cyclometalated pyridine iridium complexes (1 and 2) with terminal or internal aromatic alkynes were studied. Terminal alkynes $p-\mathrm{XC}_{6} \mathrm{H}_{4} \mathrm{C} \equiv \mathrm{CH}(\mathrm{X}=\mathrm{H}, \mathrm{MeO}$, and F) with 1 give the corresponding five- and seven-membered doubly cycloiridated complexes $4 a-c$, internal alkynes $p-\mathrm{XC}_{6} \mathrm{H}_{4} \mathrm{C} \equiv \mathrm{CC}_{6} \mathrm{H}_{4} \mathrm{X}-\mathrm{p}(\mathrm{X}=\mathrm{H}, \mathrm{MeO}$, and $\mathrm{Br})$ form the similar five- and seven-membered doubly cycloiridated complexes $(5 a, b)$ and/or di-insertion products $(6 a, c)$, whereas the acyl alkyne $\mathrm{PhC} \equiv \mathrm{CCOPh}$ affords the novel spiro-metalated complex 7. For complex 2 , internal alkynes $p-\mathrm{XC}_{6} \mathrm{H}_{4} \mathrm{C} \equiv \mathrm{CC}_{6} \mathrm{H}_{4} \mathrm{X}-\mathrm{p}(\mathrm{X}=\mathrm{H}, \mathrm{MeO}$, and $\mathrm{Br})$ form similar five- and seven-membered doubly cycloiridated complexes $(8 \mathrm{a}-\mathrm{c})$. However, in the case of $\mathrm{PhC} \equiv \mathrm{CCOPh}$, the reaction gives the novel four-membered cyclometalated complex 9. These results suggest that the products formed by alkyne insertion reactions of the six-membered cycloiridated pyridine complexes are very diverse. Plausible pathways for the formation of these novel insertion products were proposed. Molecular structures of seven cyclometalated complexes were determined by $\mathrm{X}$-ray diffraction.
\end{abstract}

\section{Introduction}

In the last decade, the reactions of $\mathrm{N}$-containing substrates with alkynes catalyzed by transition metal complexes (Rh and Ir) have been widely studied, which is mainly due to the reactions providing an economic and convenient method to generate organic heterocyclic compounds. ${ }^{1}$ Up to now, the generally accepted catalytic cycle mainly includes: (i) initial coordination of the transition metal center (Rh and Ir) via a donor atom (N), (ii) a geometrically accessible $\mathrm{C}-\mathrm{H}$ bond is activated by the metal atom to give a five-membered ring, (iii) alkyne insertion into the cyclometalated $\mathrm{M}-\mathrm{C}$ bond $(\mathrm{M}=\mathrm{Rh}, \mathrm{Ir})$ to form a sevenmembered intermediate, and (iv) reductive elimination to give the organic heterocyclic product. In order to improve understanding selectivity and reactivity issues in the catalytic

Tianjin Key Laboratory of Structure and Performance for Functional Molecules, Key Laboratory of Inorganic-Organic Hybrid Functional Material Chemistry, Ministry of Education, College of Chemistry, Tianjin Normal University, Tianjin 300387, People's Republic of China. E-mail: hxxyzbl@gmail.com; Fax: +86 22 23766532; Tel: +862223766515

$\dagger$ Electronic supplementary information (ESI) available. CCDC 1589484-1589490. For ESI and crystallographic data in CIF or other electronic format see DOI: 10.1039/c7ra13547e processes, synthesis of five-membered cyclometalated complexes $^{2-9}$ and their stoichiometric reactions with alkynes have been well studied. ${ }^{10}$ For example, cyclometalation of $\left[\mathrm{Cp}^{*} \mathrm{MCl}_{2}\right]_{2}(\mathrm{M}=\mathrm{Ir}, \mathrm{Rh})$ with 2-phenylpyridine has been widely reported, the resulting five-membered cyclometalated products $(\mathrm{M}=\mathrm{Ir}, \mathrm{Rh})$ were formed either in stoichiometric reactions or in catalytic ones..$^{2 a, c, 3,4, \mathbf{c}, 10 f}$ The insertion reactions of alkynes were summarized in Scheme 1, the most common products were seven-membered cyclometalated compounds (I) which were formed by 1,2-alkyne insertion into $\mathrm{M}-\mathrm{C}$ bond of fivemembered ring. ${ }^{10 c, d_{f} f}$ In the case of phenylacetylene, the reactions afforded the double-insertion products (II). ${ }^{10 d}$ When the reactions were carried out in the presence of $\operatorname{NaBAr}_{4}^{\mathrm{F}}$, the competition of 1,2-alkyne insertion and vinylidene rearrangement/1,1-insertion was observed to generate the corresponding ion pair compounds (III and IV). ${ }^{3 a}$ However, synthesis of the similar six-membered cyclometalated complexes (Rh and Ir) $)^{2 b, 3 b, 11}$ and their stoichiometric reactions with alkynes were less reported. For comparison of reactivity and understanding the possibility of existence in the catalytic process, we now report the synthesis and structures of sixmembered cyclometalated pyridine complexes $(\mathrm{M}=\mathrm{Ir}, \mathrm{Rh})$ and their insertion reactions with aromatic alkynes. 


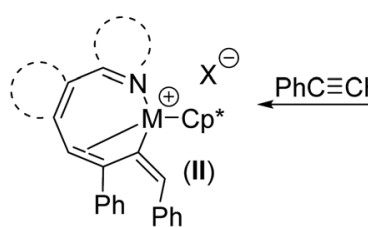

ref. $10 \mathrm{~d}$

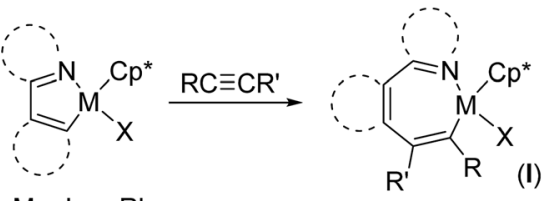

$\mathrm{M}=\mathrm{Ir}$ or $\mathrm{Rh}$

$\mathrm{ArC} \equiv \mathrm{CAr}$ $\mathrm{NaBArF}_{4}$

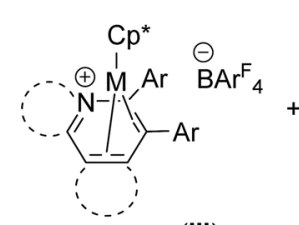

(III)

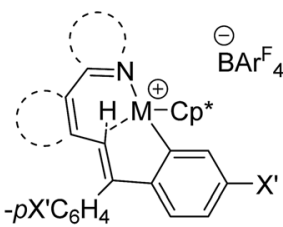

(IV) $\mathrm{X}^{\prime}=\mathrm{H}, \mathrm{Me}, \mathrm{Cl}$

\section{$\mathrm{R}=\mathrm{R}^{\prime}=\mathrm{CO}_{2} \mathrm{Me}$}

$\mathrm{R}=\mathrm{R}^{\prime}=\mathrm{Ph}$

$\mathrm{R}=\mathrm{Ph}, \mathrm{R}^{\prime}=\mathrm{H}$

ref. $10 \mathrm{c}, \mathrm{f}$

$\mathrm{R}=\mathrm{CO}_{2} \mathrm{Me}, \mathrm{R}^{\prime}=\mathrm{Me}, \mathrm{Ph}$, or $\mathrm{CF}_{3}$

$\mathrm{R}=\mathrm{R}^{\prime}=\mathrm{H}$

ref. $10 d$

Scheme 1 Reactions of five-membered cyclometalated complexes with alkynes.

\section{Results and discussion}

\section{Reaction of $\left[\mathrm{Cp}^{*} \mathrm{MCl}_{2}\right]_{2}(\mathrm{M}=\mathrm{Ir}, \mathrm{Rh})$ with 2-benzoylpyridine or 2-benzylpyridine}

By the modified methods reported by Davies ${ }^{2 b}$ and Jones, ${ }^{3 b}$ we reinvestigated the reaction of $\left[\mathrm{Cp} * \mathrm{MCl}_{2}\right]_{2}(\mathrm{M}=\mathrm{Ir}, \mathrm{Rh})$ with 2benzoylpyridine or 2-benzylpyridine in the presence of NaOAc in the refluxing methanol, which was slightly different from the reported reaction conditions, $\mathrm{CH}_{2} \mathrm{Cl}_{2}$ as solvent at room temperature. Cyclometalation similarly occurred to yield the corresponding six-membered ring products 1-3 via an intramolecular $\mathrm{C}\left(\mathrm{sp}^{2}\right)-\mathrm{H}$ bond activation (Scheme 2). All spectroscopic data we obtained for $\mathbf{1}$ and $\mathbf{2}$ are in complete agreement with those published by Davies and Jones, as well as the high yields (85\% and 92\%). It is worth mentioning that the similar cyclometalated rhodium complex 3 was successfully formed and isolated in our current conditions, although the yield is relatively low (41\%). This is different from the product obtained from the same reaction but in the conditions of $\mathrm{CH}_{2} \mathrm{Cl}_{2}$ as solvent at room temperature, which gave a $\mathrm{Cp}^{*} \mathrm{C}-\mathrm{H}$ bond activated complex. ${ }^{2 b}$ The reaction of 2-benzylpyridine with $\left[\mathrm{Cp} * \mathrm{RhCl}_{2}\right]_{2}$ and $\mathrm{NaOAc}$ was also attempted in the refluxing methanol, unfortunately it failed to give any products except the starting materials. The ${ }^{1} \mathrm{H}$ NMR spectrum of 3 showed the expected four signals for an orthometalated phenyl group and four for the pyridine group, one singlet at $\delta=1.34 \mathrm{ppm}$ for $\mathrm{Cp}^{*}$ group. The ${ }^{13} \mathrm{C}$ NMR spectrum showed the metalated carbon atom at $\delta=172.9 \mathrm{ppm}\left({ }^{1} J_{\mathrm{Rh}-\mathrm{C}}=30.0\right)$, and the carbonyl group at
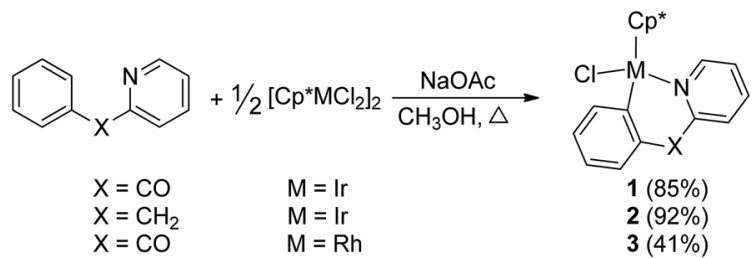

Scheme 2 Reaction of $\left[\mathrm{Cp} * \mathrm{MCl}_{2}\right]_{2}(\mathrm{M}=\mathrm{Ir}$, Rh) with 2-benzoylpyridine or 2-benzylpyridine. $\delta=191.2 \mathrm{ppm}$. The product 3 was recrystallized from dichloromethane/hexane and the structure was determined by $\mathrm{X}$-ray crystallography.

The structure of 3 is shown in Fig. 1 with selected bond lengths and angles, which reveals a classic three-legged piano stool geometry. The six-membered ring in the structure confirms the activation of a $\mathrm{C}\left(\mathrm{sp}^{2}\right)-\mathrm{H}$ bond on $\alpha$ position of phenyl ring. The $\mathrm{Rh}(1)-\mathrm{N}(1)$ bond distance is 2.079(4) $\AA$, which is slightly shorter than those (2.099(3) and 2.1000(15) A) in fivemembered ring analogues $\mathrm{Cp} * \mathrm{RhCl}(\mathrm{L})\left(\mathrm{HL}=2\right.$-phenylpyridine ${ }^{2 c}$ and 2-(4-methoxyphenyl)pyridine). ${ }^{3 a}$

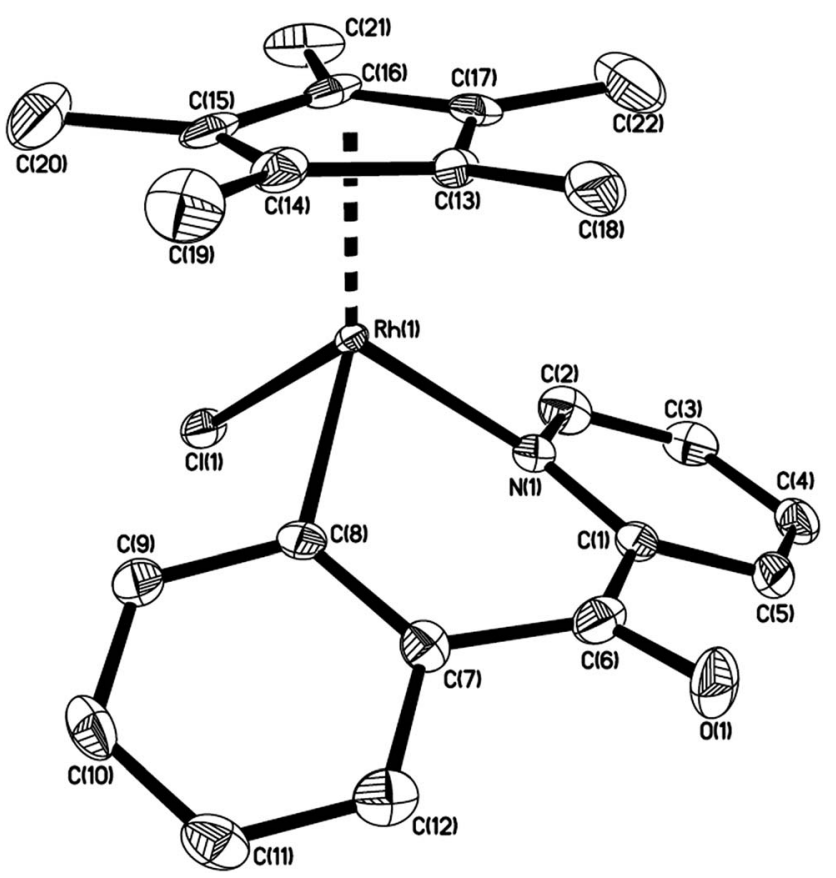

Fig. 1 Thermal ellipsoid drawing of 3 showing the labeling scheme and $50 \%$ probability ellipsoids; hydrogens are omitted for clarity. Selected bond lengths $[\AA]$ and angles $\left[{ }^{\circ}\right]$ are $\mathrm{Rh}(1)-\mathrm{Cl}(1) 2.4125(15)$, $\mathrm{Rh}(1)-\mathrm{N}(1)$ 2.079(4), $\mathrm{Rh}(1)-\mathrm{C}(8)$ 2.017(5), $\mathrm{Rh}(1)-\mathrm{Cp}$ (centroid) 1.826, $\angle \mathrm{Cl}(1)-\mathrm{Rh}(1)-\mathrm{N}(1)$ 89.35(15), $\angle \mathrm{Cl}(1)-\mathrm{Rh}(1)-\mathrm{C}(8)$ 89.55(16), $\angle \mathrm{C}(8)-$ $\mathrm{Rh}(1)-\mathrm{N}(1)$ 87.33(19). 


\section{Reactions of 1 with terminal alkynes}

Reactions of 1 with arylacetylene $p-\mathrm{XC}_{6} \mathrm{H}_{4} \mathrm{C} \equiv \mathrm{CH}(\mathrm{X}=\mathrm{H}, \mathrm{MeO}$, and $\mathrm{F}$ ) in methanol at room temperature resulted in the fivemembered and seven-membered doubly cyclometalated complexes $\mathbf{4 a - c}$ in moderate yields (Scheme 3). Obviously, the products were different with those double-insertion compounds (II in Scheme 1) generated from the similar reactions of fivemembered cyclometalated complexes ( $\mathrm{M}=\mathrm{Ir}$, Rh) with phenylacetylene. ${ }^{\mathbf{1 0 d}}$ It was observed that the reactions with arylacetylene containing an electron-donating substituent ( $p$-OMe) is faster than the reaction with that containing an electronwithdrawing substituent ( $p-\mathrm{F})$. The ${ }^{1} \mathrm{H}$ NMR spectrum of $\mathbf{4 a}$ showed eleven multiplets, integrating to $12 \mathrm{H}$, assigned to protons of three aromatic rings, one singlet at $\delta=6.81 \mathrm{ppm}$ corresponding to the only vinyl proton, and one singlet at $\delta=$ $1.45 \mathrm{ppm}$ for $\mathrm{Cp}^{*}$ group.

The structure of $\mathbf{4 c}$ is shown in Fig. 2 with selected bond lengths and angles. The iridium(III) center is coordinated by a $\eta^{5}$ $\mathrm{Cp}^{*}$, one nitrogen atom $\mathrm{N}(1)$, and two metalated carbon atoms $\mathrm{C}(13)$ and $\mathrm{C}(16)$, which come from $p-\mathrm{FC}_{6} \mathrm{H}_{4} \mathrm{C} \equiv \mathrm{CH}$. Two fused rings constitute the molecular framework, one is a fivemembered ring, and the other is a seven-membered one, they share two adjacent atoms $\operatorname{Ir}(1)$ and $C(13)$. For the fivemembered ring, all five atoms in the ring are almost in the same plane. The $\operatorname{Ir}(1)-\mathrm{N}(1)$ bond distance $(2.065(12) \AA)$ is slightly shorter than that $(2.085(3) \AA)$ in the analogue which is generated from the reaction of 2-(2,3,4,5-tetrafluorophenyl) pyridine cycloiridated complex with diphenylacetylene. ${ }^{\mathbf{1 0 a}}$

\section{Reactions of 1 with internal alkynes}

Since six-membered cyclometalated complex 1 showed different reactivity with arylacetylene from the five-membered one, the reaction of 1 with diphenylacetylene was carried out under the same conditions. Unfortunately, neither the expected 1,2-alkyne insertion product nor the double-insertion product was obtained except the starting materials. However, when the reaction was performed in the presence of $\mathrm{NaBAr}_{4}{ }_{4}$ in dichloroethane at $50{ }^{\circ} \mathrm{C}$, the five-membered and sevenmembered doubly cyclometalated complex 5a was formed, which showed the similar structure to complexes $4 \mathbf{4}-\mathbf{c}$ (Scheme 4). Besides, the reaction also produced the other product 6a in which 2 equiv. of diphenylacetylene has involved, but different from the double-insertion product mentioned in Scheme $1 .^{10 d}$ We considered that $\mathrm{NaBAr}^{\mathrm{F}}{ }_{4}$ was required in this

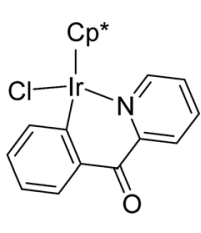

1

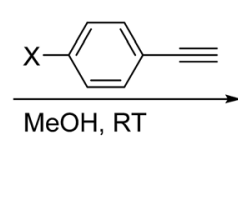

$$
\begin{aligned}
& X=H \\
& X=M e O \\
& X=F
\end{aligned}
$$

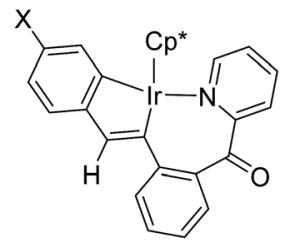

$4 a(48 \%)$

$4 \mathrm{~b}(52 \%)$

$4 \mathrm{c}(42 \%)$
Scheme 3 Reactions of 1 with arylacetylenes.

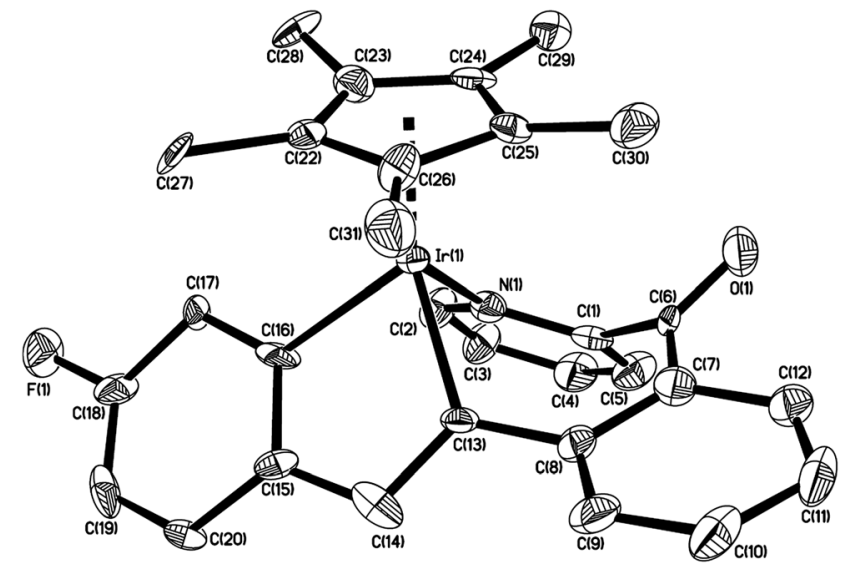

Fig. 2 Thermal ellipsoid drawing of $4 c$ showing the labeling scheme and $30 \%$ probability ellipsoids; hydrogens are omitted for clarity. Selected bond lengths $[\AA]$ and angles $\left[{ }^{\circ}\right]$ are $\operatorname{Ir}(1)-N(1) 2.065(12), \operatorname{Ir}(1)-$ $C(13) 2.062(12), \operatorname{Ir}(1)-C(16) 2.090(13), C(13)-C(14) 1.378(19), C(8)-$ $C(13) 1.455(19), \operatorname{Ir}(1)-C p($ centroid) 1.862, $\angle N(1)-\operatorname{Ir}(1)-C(13) 85.0(5)$, $\angle \mathrm{N}(1)-\operatorname{Ir}(1)-\mathrm{C}(16) 88.6(5), \angle \mathrm{C}(13)-\operatorname{Ir}(1)-\mathrm{C}(16) 78.3(5), \angle \operatorname{Ir}(1)-\mathrm{C}(13)-$ $C(14) 117.2(11), \angle \operatorname{Ir}(1)-C(13)-C(8) 121.1(9)$.

reaction to help to remove the chloride in $\mathbf{1}$, then the bulky diphenylacetylene ligand could readily approaching metal center for the subsequent coordination; while in the reaction of 1 with phenylacetylene, the phenylacetylene ligand is relatively less bulky which could attack the metal center directly when the chloride is leaving, so the presence of $\mathrm{NaBAr}^{\mathrm{F}}{ }_{4}$ was not necessary. Similarly, para-substituted diphenylacetylene derivatives $p$ - $\mathrm{XC}_{6} \mathrm{H}_{4} \mathrm{C} \equiv \mathrm{CC}_{6} \mathrm{H}_{4} \mathrm{X}-p$ were applied to the above reaction. When $\mathrm{X}$ was electron-donating substituent $(\mathrm{MeO})$, the reaction mainly afforded the corresponding product $\mathbf{5} \mathbf{b}$ and trace amounts of 6b, when $\mathrm{X}$ was electron-withdrawing substituent $(\mathrm{Br})$, the reaction mainly afforded the corresponding product $\mathbf{6 c}$ and trace amounts of $\mathbf{5 c}$.

The molecular structure of $\mathbf{5 a}$ was confirmed by X-ray single crystal diffraction study, which exhibited the structure similar to $4 c$. The crystal structure and crystallographic data for 5a were provided in the ESI. $\dagger$

By careful analysis of the crystal structures of $\mathbf{4 a}$ and $5 \mathbf{a}$, we found that one carbon atom is inserted into $\mathrm{Ir}-\mathrm{C}$ (phenyl) bond of $\mathbf{1}$, and the two phenyl groups in $\mathbf{5 a}$ are bound to the same carbon atom, which indicates that the migration of one phenyl group of diphenylacetylene occurs during the reaction. Besides, we also noticed that an ortho $\mathrm{C}-\mathrm{H}$ bond of phenyl group from alkyne is activated by the iridium center. Based on these results described above, we proposed a plausible pathway for the formation of 4 or 5 in Scheme 5. Firstly, the chloride of 1 dissociates to form a 16-electron cation, and the aromatic alkyne $\eta^{2}$-coordinates to metal center to give complex $\mathbf{A}$, which undergoes vinylidene rearrangement to give the phenylvinylidene intermediate $\mathbf{B}$. This is followed by 1,1-insertion of the vinylidene ligand into the $\mathrm{Ir}-\mathrm{C}$ (phenyl) bond to form $\mathbf{C}$. In the last step, intramolecular activation of an ortho $\mathrm{C}-\mathrm{H}$ bond of phenyl group occurs to build the second metallacycle, which comes with an elimination of HX to afford the final product 4 or 5. Ishii group reported similar reactions of five-membered 

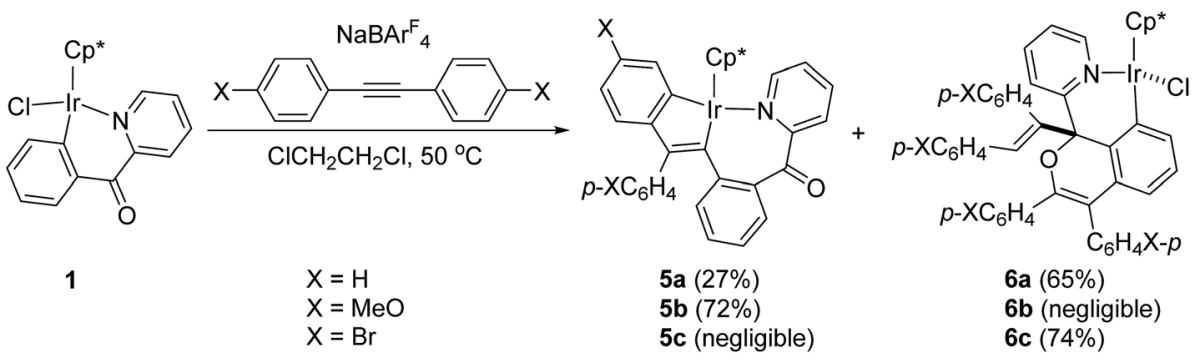

Scheme 4 Reactions of 1 with diarylacetylenes.
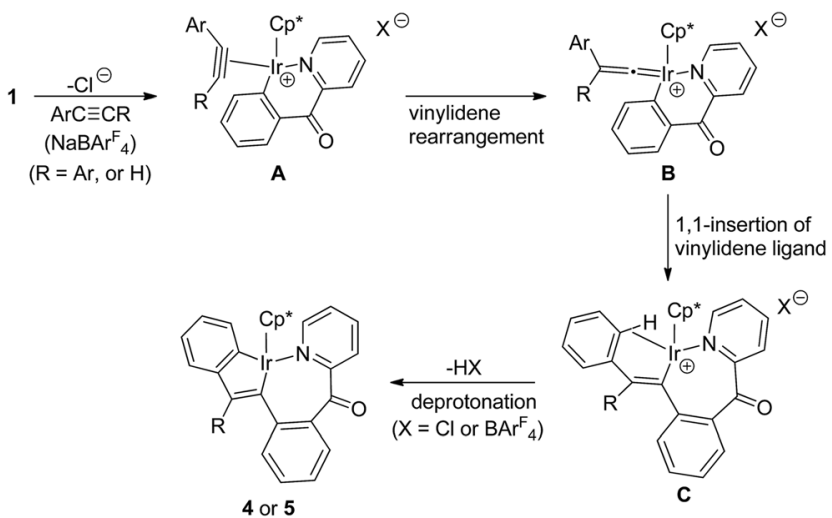

Scheme 5 A plausible pathway for formation of 4 or 5 .

cycloiridated pyridine complex with diphenylacetylene derivatives in the presence of $\mathrm{NaBAr}_{4}^{\mathrm{F}}{ }^{10 a}$ which afforded a ninemembered iridacycle complex with a Ir-(vinyl $\mathrm{CH}$ ) agnostic interaction (IV in Scheme 1), and then followed by a further stirring in $\mathrm{MeOH}$ to give the doubly cyclometalated analogues of 4 or 5. Besides, recently we reported similar reactions of fivemembered cycloiridated phosphine complex with aromatic alkynes in the absence of $\mathrm{NaBAr}_{4}^{\mathrm{F}}$, which also produced the corresponding five-membered and six-membered doubly cyclometalated products. ${ }^{12}$ Based on our results and reported examples of reactions of cycloiridated complexes with aromatic alkynes, we may deduce that this type of doubly cyclometalated complexes are another general products which formed through vinylidene rearrangement of alkynes/1,1-insertion except for the normal seven-membered cyclometalated products generated from 1,2-alkyne insertion, sometimes there exists competition between above two pathways.

The structure of $\mathbf{6 c}$ is shown in Fig. 3 with selected bond lengths and angles, which confirms that the two molecules of $p$ $\mathrm{BrC}_{6} \mathrm{H}_{4} \mathrm{C} \equiv \mathrm{CC}_{6} \mathrm{H}_{4} \mathrm{Br}-p$ are involved in building the molecular framework. The $\operatorname{Ir}(1)-\mathrm{C}(8)$ bond distance $(2.049(5) \AA)$ is slightly longer than that $(2.030(5) \AA)$ in the parent 2-benzoylpyridine cycloiridated complex; ${ }^{2 b}$ and the $\operatorname{Ir}(1)-\mathrm{N}(1)$ bond distance (2.106(5) $\AA$ ) is also slightly longer than that $(2.083(4) \AA)$; however the N-Ir-C angles are almost same $\left(86.39(19)\right.$ and $86.75(16)^{\circ}$, respectively). The angle between the pyridine and phenyl planes (originally from 2-benzoylpyridine ligand) in $6 \mathrm{c}$ is $47.2^{\circ}$, which compares with $34.9^{\circ}$ in the parent 2-benzoylpyridine cycloiridated complex. ${ }^{2 b}$ To the best of our knowledge, the similar structure of $\mathbf{6 c}$ has never been reported. Unfortunately, no plausible pathway has yet been proposed to account for the formation of $\mathbf{6 c}$.

\section{Reaction of 1 with acyl alkyne $\mathrm{PhC} \equiv \mathrm{CCOPh}$}

Apparently, in the reactions of six-membered cyclometalated complex 1 with terminal or internal aromatic alkynes, vinylidene arrangement of alkynes was more favored than 1,2-insertion into the Ir-C bond, while the latter was the main insertion mode in the reactions of five-membered cyclometalated complexes with alkynes (Scheme 1). Here we further investigated the reactivity of $\mathbf{1}$ with acyl alkyne $\mathrm{PhC} \equiv \mathrm{CCOPh}$, which

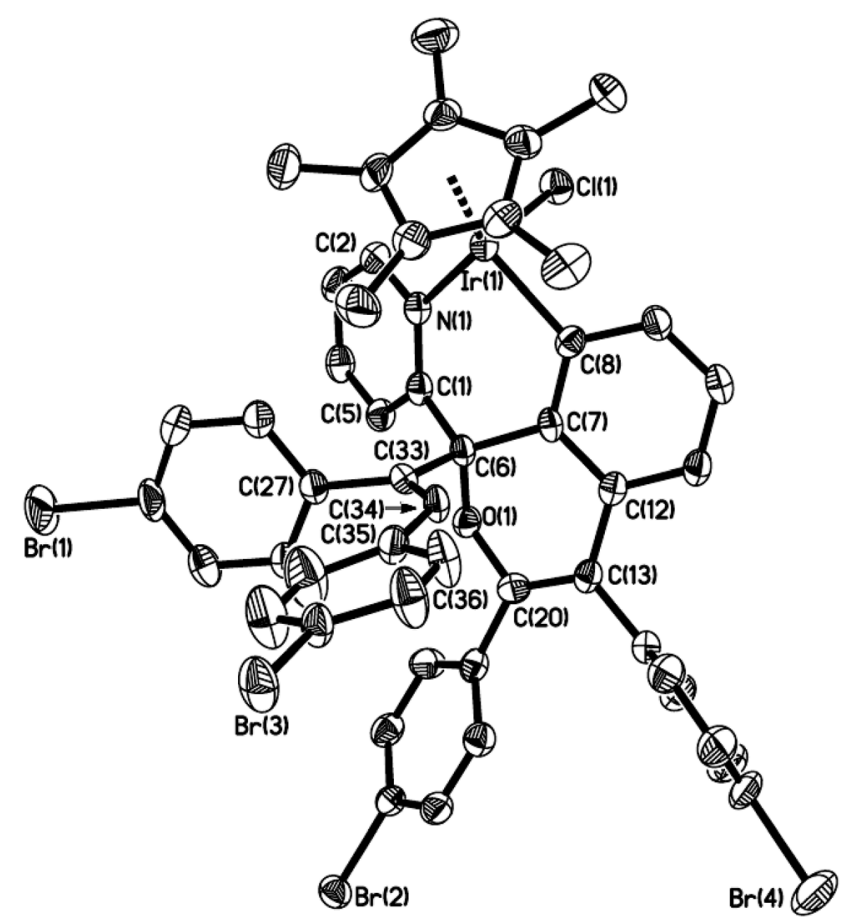

Fig. 3 Thermal ellipsoid drawing of $6 \mathrm{c}$ showing the labeling scheme and $30 \%$ probability ellipsoids; hydrogens are omitted for clarity. Selected bond lengths $[\AA]$ and angles $\left[^{\circ}\right]$ are $\operatorname{Ir}(1)-N(1) 2.106(5), \operatorname{Ir}(1)-$ $\mathrm{C}(8) 2.049(5), \operatorname{Ir}(1)-\mathrm{Cl}(1)$ 2.4122(12), $\mathrm{C}(1)-\mathrm{N}(1)$ 1.348(7), $\mathrm{C}(1)-\mathrm{C}(6)$ 1.536(7), $C(6)-C(7) 1.518(7), C(7)-C(8) 1.401(7), C(6)-C(33) 1.550(7)$, $C(6)-O(1) 1.459(6), C(33)-C(34) 1.322(8), O(1)-C(20) 1.381(6), C(13)-$ $C(20) 1.347(8), C(12)-C(13) 1.483(7), \operatorname{Ir}(1)-C p($ centroid) $1.843, \angle N(1)-$ $\operatorname{Ir}(1)-\mathrm{C}(8) \quad 86.39(19), \quad \angle \mathrm{C}(1)-\mathrm{C}(6)-\mathrm{C}(7)$ 114.1(4), $\angle \mathrm{C}(6)-\mathrm{O}(1)-\mathrm{C}(20)$ $117.5(4)$. 

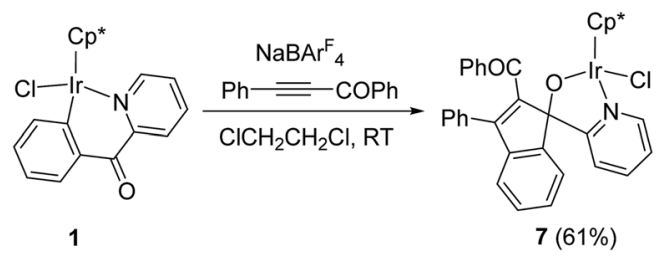

Scheme 6 Reaction of 1 with $\mathrm{PhC} \equiv \mathrm{CCOPh}$.

prefers to undergo a vinylidene arrangement as a reactive substrate. ${ }^{13}$ When a mixture of 1 with $\mathrm{PhC} \equiv \mathrm{CCOPh}$ and NaBAr ${ }_{4}{ }_{4}$ in $\mathrm{C}_{2} \mathrm{H}_{4} \mathrm{Cl}_{2}$ was stirred at room temperature for $30 \mathrm{~min}$, an orange crystal was obtained after recrystallization. X-ray diffraction study disclosed that the orange crystal was the novel spiro-metalated complex 7 (Scheme 6).

The structure of 7 was shown in Fig. 4. The iridium(III) center is coordinated by a $\eta^{5} \mathrm{Cp}$, one pyridine ligand, one chlorine atom $\mathrm{Cl}(1)$, and one metalated oxygen atom $\mathrm{O}(1)$, which comes from the bridging carbonyl group. Two spiro five-membered rings constitute the molecular framework, one is a fivemembered ring $(\mathrm{C}(16)-\mathrm{C}(17)-\mathrm{C}(18)-\mathrm{C}(23)-\mathrm{C}(30))$, and the other is a metalated five-membered one $(\operatorname{Ir}(1)-\mathrm{N}(1)-\mathrm{C}(11)-$ $\mathrm{C}(16)-\mathrm{O}(1))$, they share one carbon atom $\mathrm{C}(16)$. All five atoms in each ring are perfectly in the same plane, and the dihedral angle between these two planes is $87.5^{\circ}$, which means that they are almost perpendicular. The $\operatorname{Ir}(1)-\mathrm{N}(1)$ bond distance $(2.098(4) \AA)$ is also slightly longer than that (2.074(5) $\AA$ ) in the 2-phenylpyridine cycloiridated complex. ${ }^{2 c}$

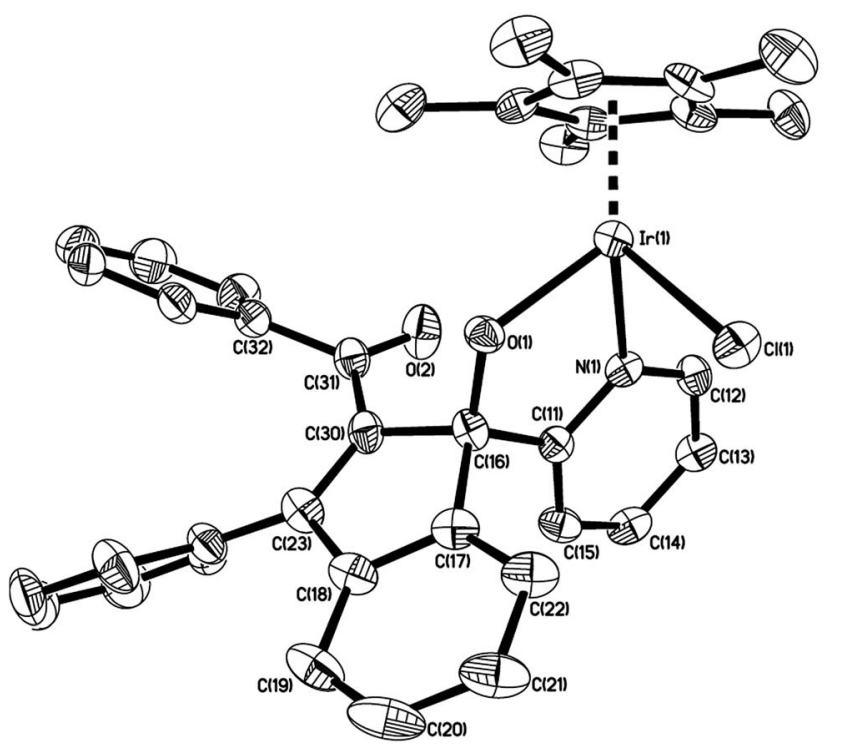

Fig. 4 Thermal ellipsoid drawing of 7 showing the labeling scheme and $30 \%$ probability ellipsoids; hydrogens are omitted for clarity. Selected bond lengths $[\AA]$ and angles $\left[{ }^{\circ}\right]$ are $\operatorname{Ir}(1)-N(1) 2.098(4), \operatorname{Ir}(1)-$ $\mathrm{O}(1) 2.080(3), \operatorname{Ir}(1)-\mathrm{Cl}(1) 2.4207(11), \mathrm{C}(16)-\mathrm{O}(1) 1.392(6), \mathrm{C}(16)-\mathrm{C}(11)$ 1.534(6), $C(16)-C(17)$ 1.525(6), $C(16)-C(30)$ 1.567(6), $C(23)-C(30)$ 1.347(7), $C(18)-C(23) 1.491(7), \operatorname{Ir}(1)-C p($ centroid) $1.766, \angle N(1)-\operatorname{Ir}(1)-$ $\mathrm{O}(1) \quad 77.27(13), \quad \angle \mathrm{C}(11)-\mathrm{C}(16)-\mathrm{O}(1) \quad 111.3(4), \quad \angle \mathrm{C}(17)-\mathrm{C}(16)-\mathrm{C}(30)$ 99.7(4).

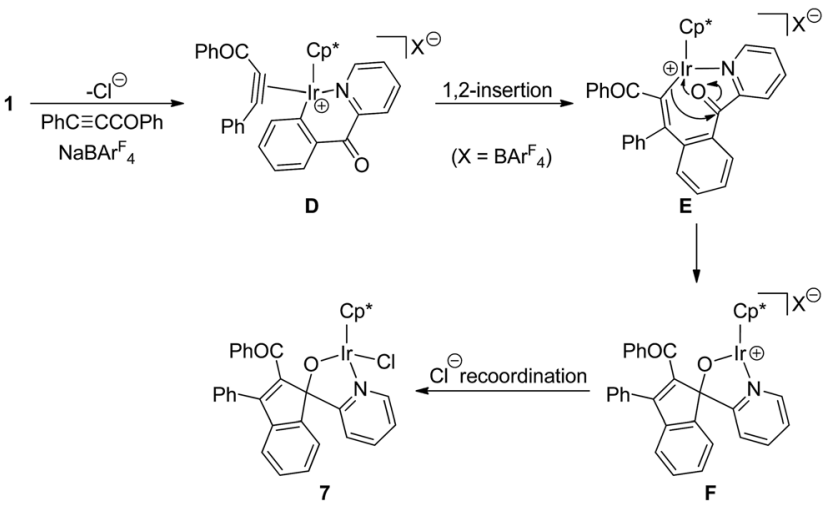

Scheme 7 A plausible pathway for formation of 7.

By careful analysis of the crystal structure of 7, we found that the bridging carbonyl group was involved in the reaction. A plausible pathway for the formation of 7 was proposed in Scheme 7. Firstly, the chloride of $\mathbf{1}$ dissociates to free up a coordinate space for aromatic alkyne, and then generate a $\eta^{2}$-alkyne complex $\mathbf{D}$, which undergoes 1,2-alkyne insertion to give the eight-membered metallacycle $\mathbf{E}$. The most noteworthy is the regioselectivity of the alkyne insertion in this system, the benzoyl group is found on the carbon atom adjacent to the metal, while the phenyl group is on the carbon atom adjacent to the phenyl pyridine. This regioselectivity is the same as that found by Ishii for the reaction of this alkyne with the similar five-membered cycloiridated pyridine complex, ${ }^{\mathbf{1 0 a}}$ also the same as that reported by Davies in the reaction of ester alkyne $\mathrm{PhC} \equiv \mathrm{CCO}_{2}$ Et with the five-membered cycloiridated oxazoline complex. ${ }^{10 e}$ Subsequently, this is followed by an intramolecular nucleophilic addition of metal organic reagent to the bridging carbonyl group to form the spiro-metalated intermediate $\mathbf{F}$. In the last step, recoordination of chlorine to metal center in $\mathbf{F}$ forms the final neutral product 7. Apparently, 1,2-insertion into the $\mathrm{Ir}-\mathrm{C}_{\text {phenyl }}$ bond was more favored in this case than vinylidene rearrangement of alkyne.

\section{Reactions of 2 with internal alkynes}

For comparison, we also studied the reactions of the other sixmembered cycloiridated pyridine complex 2 with diarylacetylenes. When a mixture of 2 with $p-\mathrm{XC}_{6} \mathrm{H}_{4} \mathrm{C} \equiv \mathrm{CC}_{6} \mathrm{H}_{4} \mathrm{X}-p$ ( $\mathrm{X}=\mathrm{H}, \mathrm{MeO}$, or $\mathrm{Br}$ ) and $\mathrm{NaBAr}^{\mathrm{F}}{ }_{4}$ in $\mathrm{C}_{2} \mathrm{H}_{4} \mathrm{Cl}_{2}$ was stirred at room temperature for $0.5-1.5 \mathrm{~h}$, the five-membered and sevenmembered doubly cyclometalated complex 8a-c was formed, which showed the similar structure to complex 5a-c (Scheme 8). In this case, there was no other products obtained, which was different from the case of $\mathbf{1}$, the latter also formed the other product $\mathbf{6 a}$, the two diarylacetylene involved product. For the effect of substituent on the reactivity, it was observed that the reaction with arylacetylene containing an electron-donating substituent ( $p$-OMe) is faster than the reaction with that containing an electron-withdrawing substituent $(p-\mathrm{F})$, which is consistent with the case of $\mathbf{1}$.

The structure of $\mathbf{8 b}$ is shown in Fig. 5. The iridium(III) center is coordinated by a $\eta^{5} \mathrm{Cp}^{*}$, one nitrogen atom $\mathrm{N}(1)$, and two 
<smiles></smiles>

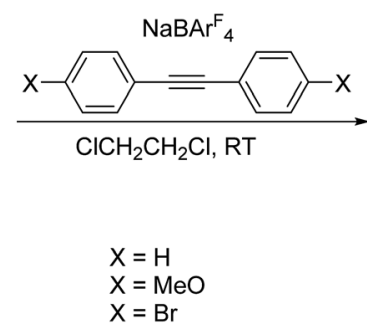

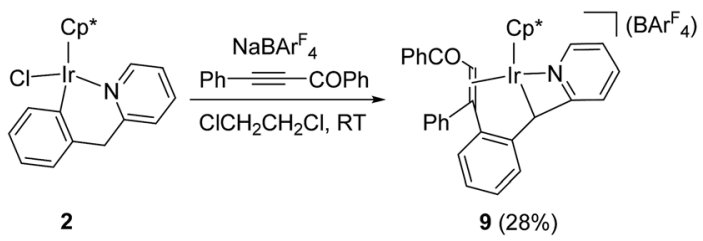

Scheme 9 Reaction of 2 with $\mathrm{PhC} \equiv \mathrm{CCOPh}$.

Scheme 8 Reactions of 1 with diarylacetylenes.

metalated carbon atoms $\mathrm{C}(23)$ and $\mathrm{C}(26)$, which come from $p$ - $\mathrm{MeOC}_{6} \mathrm{H}_{4} \mathrm{C} \equiv \mathrm{CC}_{6} \mathrm{H}_{4} \mathrm{OMe}-p$. Two fused rings constitute the molecular framework, one is a five-membered ring, and the other is a seven-membered one, they share two adjacent atoms $\operatorname{Ir}(1)$ and $\mathrm{C}(23)$. For the five-membered ring, all five atoms in this ring are almost in the same plane. $\operatorname{The} \operatorname{Ir}(1)-\mathrm{N}(1)$ bond distance $(2.103(4) \AA)$ is slightly shorter than that $(2.065(12) \AA)$ in $4 \mathbf{c}$, and almost the same as that $(2.088(6) \AA)$ in $\mathbf{5 a}$.

\section{Reaction of 2 with acyl alkyne $\mathrm{PhC} \equiv \mathrm{CCOPh}$}

For comparison with $\mathbf{1}$, reaction of six-membered cyclometalated complex 2 was similarly investigated. When a mixture of 2 with $\mathrm{PhC} \equiv \mathrm{CCOPh}$ and $\mathrm{NaBAr}_{4}^{\mathrm{F}}$ in $\mathrm{C}_{2} \mathrm{H}_{4} \mathrm{Cl}_{2}$ was stirred at

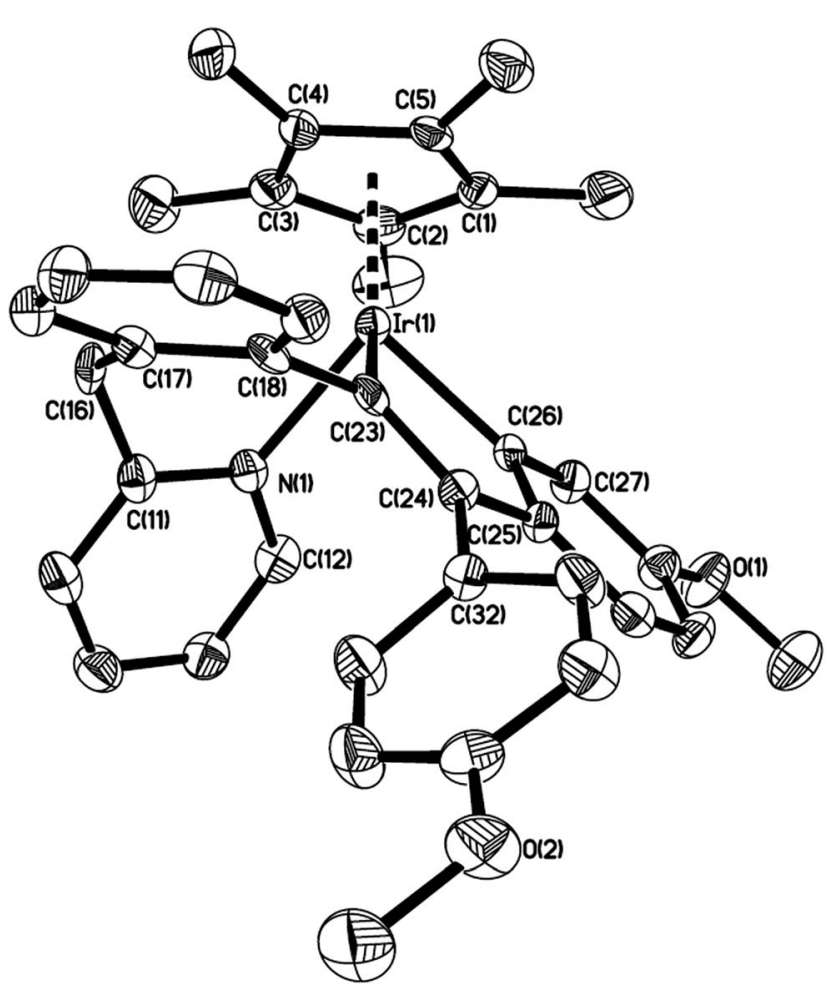

Fig. 5 Thermal ellipsoid drawing of $8 \mathrm{~b}$ showing the labeling scheme and $30 \%$ probability ellipsoids; hydrogens are omitted for clarity. Selected bond lengths $[\AA]$ and angles $\left[{ }^{\circ}\right]$ are $\operatorname{Ir}(1)-N(1) 2.103(4), \operatorname{Ir}(1)-$ $C(23) 2.085(4), \operatorname{Ir}(1)-C(26) 2.035(4), C(23)-C(24) 1.364(5), C(18)-C(23)$ 1.485(6), $\operatorname{Ir}(1)-\mathrm{Cp}$ (centroid) 1.878, $\angle \mathrm{N}(1)-\operatorname{Ir}(1)-\mathrm{C}(23)$ 81.31(15), $\angle \mathrm{N}(1)-$ $\operatorname{Ir}(1)-C(26) 88.06(15), \quad \angle C(23)-\operatorname{Ir}(1)-C(26)$ 78.34(17), $\angle \operatorname{Ir}(1)-C(23)-$ $\mathrm{C}(24) 116.4(3), \angle \operatorname{Ir}(1)-\mathrm{C}(23)-\mathrm{C}(18) 122.7(3)$.

room temperature for $25 \mathrm{~min}$, a yellow crystal was obtained after recrystallization. X-ray diffraction study disclosed that the yellow crystal was the novel four-membered cyclometalated complex 9 (Scheme 9).

The structure of 9 was shown in Fig. 6. For clarity, the anion $\mathrm{BAr}_{4}{ }_{4}^{-}$part is omitted. The iridium cationic center is coordinated by a $\eta^{5} \mathrm{Cp}^{*}$, a $\eta^{2} \mathrm{C}=\mathrm{C}$ double bond, one nitrogen atom $\mathrm{N}(1)$, and one metalated carbon atoms $\mathrm{C}(16)$, which comes from the bridging methylene group. The four-membered ring (Ir(1)$\mathrm{N}(1)-\mathrm{C}(15)-\mathrm{C}(16))$ adopts a nonplanar "puckered" conformation. The $\operatorname{Ir}(1)-\mathrm{C}(16)$ bond distance is $2.125(4) \AA$, which is shorter than those $(2.235(4)$ and 2.193(4) $\AA)$ in $\operatorname{Ir}(1)\left(\eta^{2}-(\mathrm{C}(23)=\right.$ $\mathrm{C}(30)))$ unit, but longer than that (2.062(12) $\AA)$ in five-membered metallacycle analogue $\mathbf{4 c}$, which might be ascribed to the strain of four-membered ring.

By careful analysis of the crystal structure of $\mathbf{9}$, we found that the bridging methylene group was involved in the reaction. We proposed a plausible pathway for the formation of $\mathbf{9}$ in Scheme 10. The first two steps are similar to that for the formation of 7 , which afford the corresponding $\eta^{2}$-alkyne

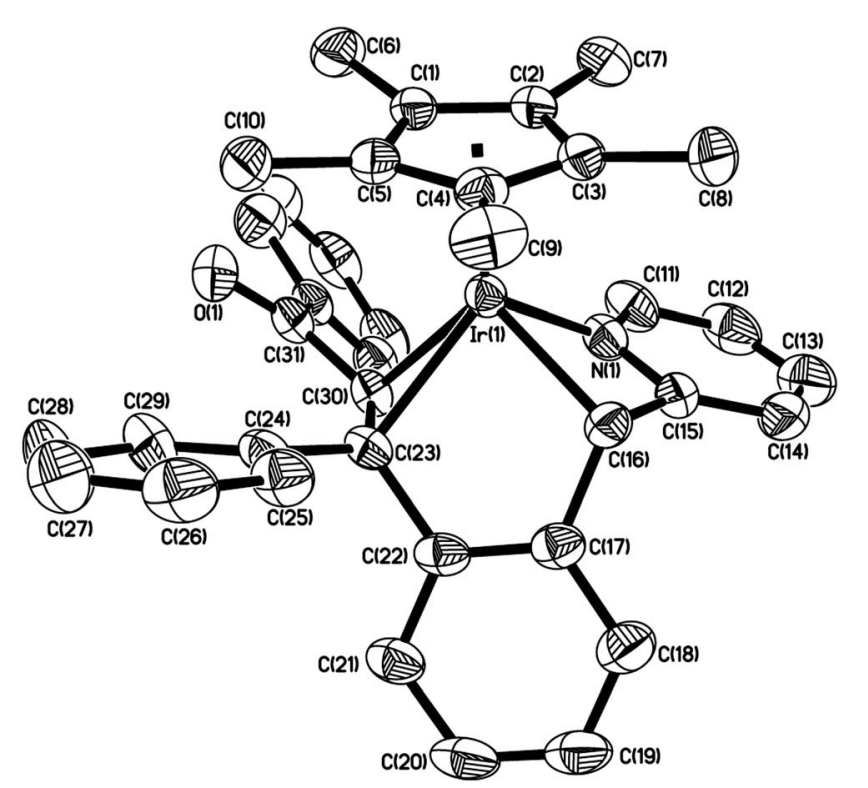

Fig. 6 Thermal ellipsoid drawing of 9 showing the labeling scheme and $30 \%$ probability ellipsoids; anion and hydrogens are omitted for clarity. Selected bond lengths $[\AA]$ and angles $\left[{ }^{\circ}\right]$ are $\operatorname{Ir}(1)-N(1) 2.084(3)$, $\operatorname{Ir}(1)-C(16) 2.125(4), \operatorname{Ir}(1)-C(23) 2.235(4), \operatorname{Ir}(1)-C(30) 2.193(4), C(23)-$ $\mathrm{C}(30)$ 1.505(6), $\operatorname{Ir}(1)-\mathrm{Cp}$ (centroid) 1.891, $\angle \mathrm{N}(1)-\operatorname{Ir}(1)-\mathrm{C}(16) 64.44(15)$, $\angle C(16)-\operatorname{Ir}(1)-C(23) 80.96(15), \angle C(23)-\operatorname{Ir}(1)-C(30) 37.80(14), \angle C(24)-$ $C(23)-C(30)$ 126.5(4), $\angle C(23)-C(30)-C(31)$ 130.9(4), $\angle C(16)-C(17)-$ $\mathrm{C}(22)-\mathrm{C}(23)-5.1(5), \angle \operatorname{Ir}(1)-N(1)-C(15)-C(16) 17.3(3)$. 

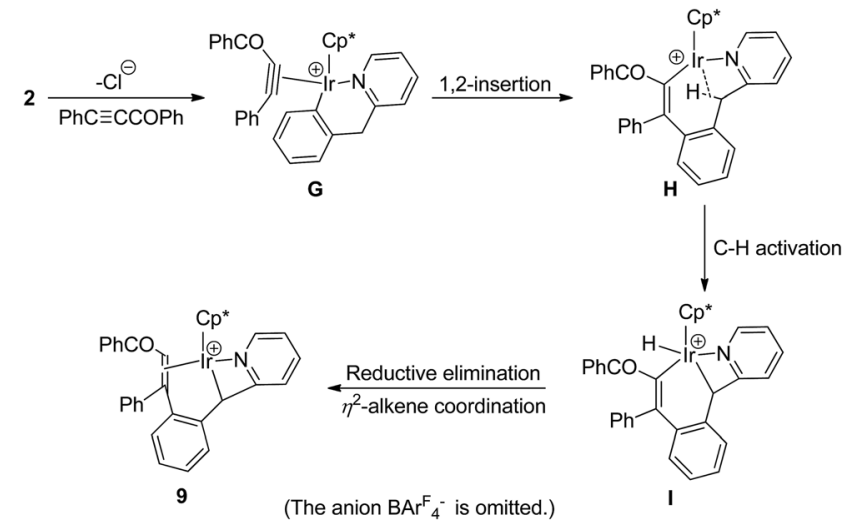

Scheme 10 A plausible pathway for formation of 9

intermediate $\mathbf{G}$ and $16 \mathrm{e}^{-}$unsaturated iridium species $\mathbf{H}$. This is followed by oxidative addition of a $\mathrm{C}-\mathrm{H}$ bond of methylene group to form I. In the final step, reductive elimination of vinyl and hydro groups on the metal to give an alkene, which subsequently coordinates to metal center in $\eta^{2}$-mode to give the final product 9. Also, 1,2-insertion into the $\mathrm{Ir}-\mathrm{C}_{\text {phenyl }}$ bond was more favored in this case than vinylidene rearrangement of alkyne.

By comparing the above two pathways for formation of 7 and 9 (Schemes 8 and 10), we observed something in common between them: both of two eight-membered metallacycle intermediates (E and $\mathbf{H}$ ) underwent an intramolecular reaction. The former is a nucleophilic addition to the bridging carbonyl group, and the latter is oxidative addition of a $\mathrm{C}-\mathrm{H}$ bond on methylene group. The driving force for the above two reactions may come from the flexibility of eight-membered rings and the stability of the resulting products. While the similar reaction of five-membered cyclometalated iridium complex [Cp* $\operatorname{IrCl}(\mathrm{ppy}-$ $\left.\left.\mathrm{F}_{4}\right)\right]$ (ppy- $\mathrm{F}_{4}=$ 2,3,4,5-tetrafluoro-6-(2-pyridyl)phenyl) with $\mathrm{PhC} \equiv \mathrm{CCOPh}$ afforded the ten-membered iridacycle complex and the vinyliridium complex by the corresponding 1,2-alkyne insertion and vinylidene rearrangement/1,1-insertion. ${ }^{\mathbf{1 0 a}}$

In summary, insertion reactions of the six-membered cyclometalated pyridine iridium complexes with terminal or internal aromatic alkynes were firstly reported, which showed different reactivity from those of the five-membered cyclometalated iridium analogues. The resulting stable products presented the wide diversity, which were formed from either 1,2-alkyne insertion or vinylidene rearrangement/1,1-alkyne insertion mode and then further intramolecular transformation. These results may also explain why $\left[\mathrm{Cp}^{*} \mathrm{IrCl}_{2}\right]_{2}$ is catalytically inactive in the catalytic reaction of 2-benzoylpyridine or 2-benzylpyridine with aromatic alkynes.

\section{Experimental}

\section{General considerations}

All reactions were carried out under nitrogen using standard Schlenk and vacuum line techniques; however, the workup was carried out in air unless stated otherwise. All solvents were distilled from appropriate drying agents under nitrogen prior to use. ${ }^{1} \mathrm{H}(400 \mathrm{MHz})$, and ${ }^{13} \mathrm{C}(100 \mathrm{MHz})$ NMR spectra were recorded on a Bruker AV400 instrument at room temperature with $\mathrm{CDCl}_{3}$ as solvent. Chemical shifts were recorded in ppm, referenced to residual ${ }^{1} \mathrm{H}$ and ${ }^{13} \mathrm{C}$ signals of the non-deuterated $\mathrm{CDCl}_{3}(\delta 7.26$ and 77.16) as internal standards. Elemental analyses were performed on a Perkin-Elmer 240C analyzer. $\left[\mathrm{Cp} \mathrm{MCl}_{2}\right]_{2}(\mathrm{M}=\mathrm{Ir}, \mathrm{Rh})$ were purchased from Strem, NaBAr ${ }_{4}{ }_{4}$ was purchased from Alfa Aesar, 2-benzoylpyridine, 2-benzylpyridine, $p-\mathrm{XC}_{6} \mathrm{H}_{4} \mathrm{C} \equiv \mathrm{CH}(\mathrm{X}=\mathrm{H}, \mathrm{MeO}$, and $\mathrm{F})$, and $p-\mathrm{XC}_{6} \mathrm{H}_{4}$ $\mathrm{C} \equiv \mathrm{CC}_{6} \mathrm{H}_{4} \mathrm{X}-p(\mathrm{X}=\mathrm{H}$ and $\mathrm{Br}$ ) were purchased from SigmaAldrich and used as received. $p$ - $\mathrm{MeOC}_{6} \mathrm{H}_{4} \mathrm{C} \equiv \mathrm{CC}_{6} \mathrm{H}_{4} \mathrm{MeO}-p^{\mathbf{1 4}}$ and $\mathrm{PhC} \equiv \mathrm{CCOPh}^{15}$ were synthesized according to the literature.

General procedures for the reactions of $\left[\mathrm{Cp}^{*} \mathbf{M C l}_{2}\right]_{2}(\mathbf{M}=\mathbf{I r}$, Rh) with 2-benzoylpyridine or 2-benzylpyridine

A mixture of $\left[\mathrm{Cp}^{*} \mathrm{MCl}_{2}\right]_{2}(\mathrm{M}=\mathrm{Ir}, \mathrm{Rh})(0.05 \mathrm{mmol})$, phosphine or 2-benzoylpyridine or 2-benzylpyridine (2.5 equiv.), and sodium acetate (4.0 equiv.) in methanol $(10 \mathrm{~mL})$ was stirred for $2-6 \mathrm{~h}$ at $60{ }^{\circ} \mathrm{C}$. The solvent was then removed under vacuum and the residue was chromatographed on a silica gel column with a mixture of petrol ether/ethyl acetate $(3: 1)$ as the eluent. The products were recrystallized from $n$-hexane $/ \mathrm{CH}_{2} \mathrm{Cl}_{2}(1: 1)$ at $-10{ }^{\circ} \mathrm{C}$ to afford 1-3 as orange, yellow, or red crystals.

1 , reaction time $6 \mathrm{~h}$, orange crystals ( $85 \%$ yield). The NMR data for $\mathbf{1}$ are consistent with reported data. ${ }^{2 b}$

2 , reaction time $2 \mathrm{~h}$, yellow crystals ( $92 \%$ yield). The NMR data for 2 are consistent with reported data. ${ }^{3 b}$

3 , reaction time $5 \mathrm{~h}$, red crystals (41\% yield). ${ }^{1} \mathrm{H}$ NMR $\delta 9.27$ $(\mathrm{d}, J=5.3 \mathrm{~Hz}, 1 \mathrm{H}), 8.18(\mathrm{~d}, J=7.5 \mathrm{~Hz}, 1 \mathrm{H}), 7.94(\mathrm{t}, J=7.3 \mathrm{~Hz}$, $1 \mathrm{H}), 7.87(\mathrm{dd}, J=11.2,7.7 \mathrm{~Hz}, 2 \mathrm{H}), 7.50(\mathrm{dd}, J=11.9,5.7 \mathrm{~Hz}$, $1 \mathrm{H}), 7.31(\mathrm{~d}, J=6.0 \mathrm{~Hz}, 1 \mathrm{H}), 7.09(\mathrm{dd}, J=13.6,6.0 \mathrm{~Hz}, 1 \mathrm{H}), 1.34$ (s, 15H, Cp*). ${ }^{13} \mathrm{C}\left\{{ }^{1} \mathrm{H}\right\}$ NMR: $\delta$ 191.2, $172.9(\mathrm{~d}, J=30 \mathrm{~Hz}), 156.1$, 155.3, 139.8, 138.2, 137.1, 132.2, 129.4, 127.1, 125.6, 123.6, 96.8 $(\mathrm{d}, J=6.3 \mathrm{~Hz})$, 8.7. Anal. calcd for $\mathrm{C}_{22} \mathrm{H}_{23}$ ClNORh: C, 57.97; $\mathrm{H}$, 5.09. Found: C, 57.74; H, 5.06 .

\section{General procedures for the insertion reactions of alkynes into Ir-C bond of 1}

A mixture of 1 (15 mg, $0.03 \mathrm{mmol}$ ) and terminal alkynes (5.0 equiv.) in methanol $(4 \mathrm{~mL})$ was stirred for $1 \mathrm{~h}$ at room temperature. The solvent was then removed under vacuum and the residue was chromatographed on a silica gel column with a mixture of petrol ether/ethyl acetate $(6: 1)$ as the eluent. The products were recrystallized from $n$-hexane $/ \mathrm{CH}_{2} \mathrm{Cl}_{2}$ at $-10{ }^{\circ} \mathrm{C}$ to afford $\mathbf{4 a - c}$ as red or deep red crystals.

4a, red crystals (48\% yield). ${ }^{1} \mathrm{H} \mathrm{NMR}\left(400 \mathrm{MHz}, \mathrm{CDCl}_{3}\right) \delta 8.50$ $(\mathrm{d}, J=5.1 \mathrm{~Hz}, 1 \mathrm{H}), 7.83(\mathrm{dd}, J=7.8,1.1 \mathrm{~Hz}, 1 \mathrm{H}), 7.70(\mathrm{dd}, J=5.8$, $2.7 \mathrm{~Hz}, 1 \mathrm{H}), 7.54$ (d, $J=7.8,1.5 \mathrm{~Hz}, 1 \mathrm{H}), 7.41$ (d, $J=7.5,1.3 \mathrm{~Hz}$, $1 \mathrm{H}), 7.30(\mathrm{~d}, J=6.8 \mathrm{~Hz}, 1 \mathrm{H}), 7.18-7.13(\mathrm{~m}, 1 \mathrm{H}), 7.09(\mathrm{dd}, J=7.9$, $0.9 \mathrm{~Hz}, 1 \mathrm{H}), 7.04$ (dd, $J=5.9,2.8 \mathrm{~Hz}, 1 \mathrm{H}), 6.89-6.79(\mathrm{~m}, 4 \mathrm{H}), 1.45$ (s, 15H, Cp*). ${ }^{13} \mathrm{C}\left\{{ }^{1} \mathrm{H}\right\}$ NMR: $\delta$ 194.1, 168.4, 161.1, 160.6, 156.3, 156.2, 152.6, 141.9, 136.9, 135.0, 133.2, 131.9, 130.5, 125.8, 125.1, 124.8 (two peaks), 124.5, 122.3, 121.4, 90.1, 8.8. Anal. calcd for $\mathrm{C}_{30} \mathrm{H}_{28}$ IrNO: C, 59.00; H, 4.62. Found: C, 58.85; H, 4.71.

$4 \mathbf{b}$, deep red crystals (52\% yield). ${ }^{1} \mathrm{H}$ NMR $\left(400 \mathrm{MHz}, \mathrm{CDCl}_{3}\right)$ $\delta 8.53(\mathrm{~d}, J=5.6 \mathrm{~Hz}, 1 \mathrm{H}), 7.81(\mathrm{~d}, J=7.7 \mathrm{~Hz}, 1 \mathrm{H}), 7.54(\mathrm{t}, J=$ 
$7.6 \mathrm{~Hz}, 1 \mathrm{H}), 7.38$ (d, $J=7.4 \mathrm{~Hz}, 1 \mathrm{H}), 7.33(\mathrm{~d}, J=2.3 \mathrm{~Hz}, 1 \mathrm{H}), 7.28$ $(\mathrm{d}, J=7.4 \mathrm{~Hz}, 1 \mathrm{H}), 7.15-7.07(\mathrm{~m}, 2 \mathrm{H}), 6.98(\mathrm{~d}, J=8.1 \mathrm{~Hz}, 1 \mathrm{H})$, $6.84(\mathrm{t}, J=6.8 \mathrm{~Hz}, 1 \mathrm{H}), 6.76(\mathrm{~s}, 1 \mathrm{H}), 6.44(\mathrm{~d}, J=5.6 \mathrm{~Hz}, 1 \mathrm{H}), 3.89$ (s, 3H, $\mathrm{CH}_{3}$ ), 1.45 (s, 15H, Cp*). ${ }^{13} \mathrm{C}\left\{{ }^{1} \mathrm{H}\right\}$ NMR: $\delta$ 194.2, 168.4, $163.0,156.6,156.4,154.2$, 152.5, 152.3, 141.1, 136.9, 133.2, 131.7, 130.5, 125.9, 124.8, 122.2, 121.5, 105.5, 90.0, 55.4, 8.8. Anal. calcd for $\mathrm{C}_{31} \mathrm{H}_{30} \mathrm{IrNO}_{2}$ : C, 58.11; H, 4.72. Found: C, 58.06; $\mathrm{H}, 4.57$.

4c, deep red crystals (42\% yield). ${ }^{1} \mathrm{H}$ NMR (400 $\mathrm{MHz}, \mathrm{CDCl}_{3}$ ) $\delta 8.45(\mathrm{~d}, J=5.9 \mathrm{~Hz}, 1 \mathrm{H}), 7.84-7.81(\mathrm{~m}, 1 \mathrm{H}), 7.57(\mathrm{td}, J=7.8$, $1.5 \mathrm{~Hz}, 1 \mathrm{H}), 7.44-7.38(\mathrm{~m}, 2 \mathrm{H}), 7.29(\mathrm{~s}, 1 \mathrm{H}), 7.16(\mathrm{t}, J=7.5 \mathrm{~Hz}$, $1 \mathrm{H}), 7.10(\mathrm{~d}, J=6.9 \mathrm{~Hz}, 1 \mathrm{H}), 7.00-6.95(\mathrm{~m}, 1 \mathrm{H}), 6.87(\mathrm{~m}, 1 \mathrm{H})$, $6.76(\mathrm{~s}, 1 \mathrm{H}), 6.58-6.52(\mathrm{~m}, 1 \mathrm{H}), 1.44\left(\mathrm{~s}, 15 \mathrm{H}, \mathrm{Cp}^{*}\right) .{ }^{13} \mathrm{C}\left\{{ }^{1} \mathrm{H}\right\}$ NMR: $\delta$ 194.1, 168.4, 159.1, 156.5, 156.1, 154.3, 152.6, 140.6, 137.1, 133.3, 131.8, 130.5, 125.8, 125.1, 124.9, 121.7, 121.2, 121.1, 108.0, 107.8, 90.1, 8.7. Anal. calcd for $\mathrm{C}_{30} \mathrm{H}_{27}$ FIrNO: C, 57.31; H, 4.33. Found: C, 57.43; H, 4.46 .

\section{General procedures for the insertion reactions of alkynes into $\mathrm{M}-\mathrm{C}$ bond of 1 or 2 in the presence of $\mathrm{NaBAr}_{4}^{\mathrm{F}}$}

A mixture of 1 or 2 ( $0.02 \mathrm{mmol})$, aromatic alkynes (1.2 equiv.) and $\mathrm{NaBAr}_{4}^{\mathrm{F}}$ (1.2 equiv.) in 1,2-dichloroethane $(5 \mathrm{~mL})$ was stirred for $25 \mathrm{~min}$ to $1.5 \mathrm{~h}$ at room temperature or at $50{ }^{\circ} \mathrm{C}$. The solvent was then removed under vacuum and the residue was chromatographed on a silica gel column with a mixture of petrol ether/ethyl acetate as the eluent. The products were recrystallized from $n$-hexane $/ \mathrm{CH}_{2} \mathrm{Cl}_{2}$ at $-10{ }^{\circ} \mathrm{C}$ to afford 5-9.

5a, reaction time $1 \mathrm{~h}, 50{ }^{\circ} \mathrm{C}$, orange crystals (27\% yield). ${ }^{1} \mathrm{H}$ NMR (400 MHz, $\left.\mathrm{CDCl}_{3}\right) \delta 8.37(\mathrm{~d}, J=5.8 \mathrm{~Hz}, 1 \mathrm{H}), 7.90(\mathrm{dd}, J=$ $7.8,1.3 \mathrm{~Hz}, 1 \mathrm{H}), 7.75(\mathrm{~d}, J=7.2 \mathrm{~Hz}, 1 \mathrm{H}), 7.60(\mathrm{td}, J=7.7,1.5 \mathrm{~Hz}$, $1 \mathrm{H}), 7.31(\mathrm{~m}, 1 \mathrm{H}), 7.22(\mathrm{~d}, J=6.8 \mathrm{~Hz}, 1 \mathrm{H}), 7.13(\mathrm{~m}, 1 \mathrm{H}), 7.06-$ $6.98(\mathrm{~m}, 3 \mathrm{H}), 6.95-6.89(\mathrm{~m}, 3 \mathrm{H}), 6.79(\mathrm{~m}, 2 \mathrm{H}), 6.58(\mathrm{~m}, 2 \mathrm{H}), 1.46$ (s, $\left.15 \mathrm{H}, \mathrm{Cp}^{*}\right)$. Anal. calcd for $\mathrm{C}_{36} \mathrm{H}_{32} \mathrm{IrNO}$ : C, 62.95; H, 4.70. Found: C, 63.06; H, 4.73.

6a, reaction time $1 \mathrm{~h}, 50{ }^{\circ} \mathrm{C}$, orange crystals (65\% yield). ${ }^{1} \mathrm{H}$ $\mathrm{NMR}\left(400 \mathrm{MHz}, \mathrm{CDCl}_{3}\right) \delta 9.10(\mathrm{dd}, J=5.9,1.4 \mathrm{~Hz}, 1 \mathrm{H}), 7.64(\mathrm{dd}, J$ $=7.6,1.2 \mathrm{~Hz}, 1 \mathrm{H}), 7.59(\mathrm{~d}, J=7.5 \mathrm{~Hz}, 1 \mathrm{H}), 7.50-7.44(\mathrm{~m}, 1 \mathrm{H}), 7.38-$ $7.31(\mathrm{~m}, 3 \mathrm{H}), 7.24$ (d, $J=7.3 \mathrm{~Hz}, 2 \mathrm{H}), 7.16-6.91(\mathrm{~m}, 14 \mathrm{H}), 6.66$ (dd, $J=9.2,7.6 \mathrm{~Hz}, 3 \mathrm{H}), 6.40(\mathrm{dd}, J=7.6,1.2 \mathrm{~Hz}, 2 \mathrm{H}), 1.54(\mathrm{~s}, 15 \mathrm{H}$, Cp*). ${ }^{13} \mathrm{C}\left\{{ }^{1} \mathrm{H}\right\}$ NMR: $\delta$ 161.9, 159.1, 146.0, 143.6, 141.6, 139.5, 138.3, 137.0, 136.5, 136.3, 136.2, 134.8, 132.8, 131.9, 129.7, 128.7 (two peaks), 128.4, 128.3, 128.2, 128.1, 127.5, 127.2 (two peaks), 127.1, 127.0, 124.8, 120.7, 120.5, 89.6, 89.3, 9.6. Anal. calcd for $\mathrm{C}_{50} \mathrm{H}_{43}$ ClIrNO: C, 66.61; H, 4.81. Found: C, 66.39; H, 4.88 .

$5 \mathbf{b}$, reaction time $40 \mathrm{~min}$, room temperature, green crystals (72\% yield). ${ }^{1} \mathrm{H}$ NMR $\left(400 \mathrm{MHz}, \mathrm{CDCl}_{3}\right) \delta 8.39(\mathrm{~d}, J=5.0 \mathrm{~Hz}, 1 \mathrm{H})$, $7.88(\mathrm{dd}, J=7.8,1.1 \mathrm{~Hz}, 1 \mathrm{H}), 7.59(\mathrm{td}, J=7.8,1.4 \mathrm{~Hz}, 1 \mathrm{H}), 7.40$ $(\mathrm{d}, J=2.5 \mathrm{~Hz}, 1 \mathrm{H}), 7.21(\mathrm{~d}, J=6.9 \mathrm{~Hz}, 1 \mathrm{H}), 7.03$ (d, $J=7.5$, $1.4 \mathrm{~Hz}, 1 \mathrm{H}), 6.92(\mathrm{t}, J=7.1 \mathrm{~Hz}, 1 \mathrm{H}), 6.80(\mathrm{~m}, 1 \mathrm{H}), 6.67(\mathrm{~m}, 4 \mathrm{H})$, $6.58(\mathrm{~d}, J=7.6 \mathrm{~Hz}, 1 \mathrm{H}), 6.52(\mathrm{~d}, J=8.2 \mathrm{~Hz}, 1 \mathrm{H}), 6.37(\mathrm{dd}, J=8.3$, $2.5 \mathrm{~Hz}, 1 \mathrm{H}), 3.88\left(\mathrm{~s}, 3 \mathrm{H}, \mathrm{CH}_{3}\right), 3.72\left(\mathrm{~s}, 3 \mathrm{H}, \mathrm{CH}_{3}\right), 1.46(\mathrm{~s}, 15 \mathrm{H}$, Cp*). ${ }^{13} \mathrm{C}\left\{{ }^{1} \mathrm{H}\right\}$ NMR: $\delta$ 194.1, 168.6, 162.9, 157.3, 157.2, 154.5, $152.6,150.1,148.7,137.1,134.0,132.3,132.1,131.7,130.3$, 129.2, 124.4, 124.2, 123.7, 123.1, 122.0, 113.1, 105.0, 90.3, 55.4, 55.2 , 8.8. Anal. calcd for $\mathrm{C}_{38} \mathrm{H}_{36} \mathrm{IrNO}_{3}$ : C, 61.11; H, 4.86. Found: C, 60.95; H, 4.92 . 6c, reaction time $1.5 \mathrm{~h}, 50{ }^{\circ} \mathrm{C}$, orange crystals (74\% yield). ${ }^{1} \mathrm{H}$ NMR (400 MHz, $\left.\mathrm{CDCl}_{3}\right) \delta 9.08(\mathrm{~d}, J=5.8 \mathrm{~Hz}, 1 \mathrm{H}), 7.64(\mathrm{~m}, 1 \mathrm{H})$, $7.55(\mathrm{~d}, J=4.1 \mathrm{~Hz}, 2 \mathrm{H}), 7.49(\mathrm{~d}, J=8.4 \mathrm{~Hz}, 2 \mathrm{H}), 7.24(\mathrm{~m}, 2 \mathrm{H})$, $7.20(\mathrm{~d}, J=8.4 \mathrm{~Hz}, 2 \mathrm{H}), 7.17(\mathrm{~m}, 1 \mathrm{H}), 7.14(\mathrm{~m}, 1 \mathrm{H}), 7.03$ (d, $J=$ $7.6 \mathrm{~Hz}, 2 \mathrm{H}), 6.99(\mathrm{t}, J=7.6 \mathrm{~Hz}, 2 \mathrm{H}), 6.92(\mathrm{~d}, J=8.4 \mathrm{~Hz}, 2 \mathrm{H}), 6.53-$ $6.48(\mathrm{~m}, 3 \mathrm{H}), 6.34(\mathrm{~m}, 1 \mathrm{H}), 6.21(\mathrm{~m}, 1 \mathrm{H}), 5.88(\mathrm{~m}, 1 \mathrm{H}), 1.51$ (s, 15H, Cp*). Anal. calcd for $\mathrm{C}_{50} \mathrm{H}_{39} \mathrm{Br}_{4}$ ClIrNO: C, 49.34; $\mathrm{H}, 3.23$. Found: C, 49.55; H, 3.12.

7 , reaction time $30 \mathrm{~min}$, room temperature, orange crystals (61\% yield). ${ }^{1} \mathrm{H}$ NMR $\left(400 \mathrm{MHz}, \mathrm{CDCl}_{3}\right) \delta 8.64(\mathrm{~d}, J=5.4 \mathrm{~Hz}, 1 \mathrm{H})$, $7.70(\mathrm{~s}, 3 \mathrm{H}), 7.52(\mathrm{dd}, J=11.0,4.3 \mathrm{~Hz}, 2 \mathrm{H}), 7.28(\mathrm{~d}, J=6.9 \mathrm{~Hz}$, $1 \mathrm{H}), 7.25-7.20(\mathrm{~m}, 5 \mathrm{H}), 7.16-7.07(\mathrm{~m}, 5 \mathrm{H}), 6.78(\mathrm{~d}, J=8.0 \mathrm{~Hz}$, $1 \mathrm{H}), 1.49$ (s, 15H, Cp*). Anal. calcd for $\mathrm{C}_{37} \mathrm{H}_{33} \mathrm{ClIrNO}_{2}$ : C, 59.15; $\mathrm{H}, 4.43$. Found: $\mathrm{C}, 59.13 ; \mathrm{H}, 4.61$.

8a, reaction time $40 \mathrm{~min}$, room temperature, brown crystals (34\% yield). ${ }^{1} \mathrm{H}$ NMR (400 MHz, $\left.\mathrm{CDCl}_{3}\right) \delta 7.68(\mathrm{t}, J=7.3 \mathrm{~Hz}, 2 \mathrm{H})$, 7.45-7.42 (m, 1H), $7.15(\mathrm{~m}, 3 \mathrm{H}), 7.11(\mathrm{dd}, J=8.3,7.1 \mathrm{~Hz}, 1 \mathrm{H})$, $6.84(\mathrm{td}, J=7.4,1.5 \mathrm{~Hz}, 2 \mathrm{H}), 6.80(\mathrm{~m}, 4 \mathrm{H}), 6.76-6.68(\mathrm{~m}, 2 \mathrm{H})$, $6.62(\mathrm{~d}, J=7.1 \mathrm{~Hz}, 1 \mathrm{H}), 6.41(\mathrm{dd}, J=7.4,1.3 \mathrm{~Hz}, 1 \mathrm{H}), 4.14(\mathrm{~d}, J=$ $19.2 \mathrm{~Hz}, 1 \mathrm{H}$ ), 3.91 (d, $J=19.2 \mathrm{~Hz}, 1 \mathrm{H}), 1.67$ (d, $J=3.3 \mathrm{~Hz}, 15 \mathrm{H}$, Cp*). Anal. calcd for $\mathrm{C}_{36} \mathrm{H}_{34} \mathrm{IrN}$ : C, 64.26; H, 5.09. Found: C, 64.11; H, 5.22.

$\mathbf{8 b}$, reaction time $25 \mathrm{~min}$, room temperature, brown crystals (33\% yield). ${ }^{1} \mathrm{H}$ NMR $\left(400 \mathrm{MHz}, \mathrm{CDCl}_{3}\right) \delta 8.53(\mathrm{~d}, J=4.4 \mathrm{~Hz}, 1 \mathrm{H})$, $7.51(\mathrm{~d}, J=2.6 \mathrm{~Hz}, 1 \mathrm{H}), 7.38(\mathrm{~m}, 1 \mathrm{H}), 7.27(\mathrm{~m}, 5 \mathrm{H}), 7.14(\mathrm{~d}, J=$ $7.0 \mathrm{~Hz}, 1 \mathrm{H}), 6.88(\mathrm{~m}, 1 \mathrm{H}), 6.83(\mathrm{~m}, 1 \mathrm{H}), 6.57(\mathrm{~d}, J=8.3 \mathrm{~Hz}, 1 \mathrm{H})$, $6.50(\mathrm{t}, J=6.0 \mathrm{~Hz}, 1 \mathrm{H}), 6.43(\mathrm{~d}, J=8.1 \mathrm{~Hz}, 1 \mathrm{H}), 6.34(\mathrm{~m}, 1 \mathrm{H}), 4.29$ $(\mathrm{d}, J=13.9 \mathrm{~Hz}, 1 \mathrm{H}), 4.08$ (d, $J=14.3 \mathrm{~Hz}, 1 \mathrm{H}), 3.89\left(\mathrm{~s}, 3 \mathrm{H}, \mathrm{CH}_{3}\right)$, $3.69\left(\mathrm{~s}, 3 \mathrm{H}, \mathrm{CH}_{3}\right), 1.57\left(\mathrm{~s}, 15 \mathrm{H}, \mathrm{Cp}^{*}\right)$. Anal. calcd for $\mathrm{C}_{38} \mathrm{H}_{38} \mathrm{IrNO}_{2}$ : C, 62.27; H, 5.23. Found: C, 62.22; H, 5.39.

$8 \mathrm{c}$, reaction time $1.5 \mathrm{~h}$, room temperature, brown crystals (29\% yield). ${ }^{1} \mathrm{H}$ NMR (400 MHz, $\left.\mathrm{CDCl}_{3}\right) \delta 7.70(\mathrm{~d}, J=1.9 \mathrm{~Hz}, 1 \mathrm{H})$, $7.67(\mathrm{~d}, J=8.3 \mathrm{~Hz}, 1 \mathrm{H}), 7.35(\mathrm{~m}, 1 \mathrm{H}), 7.26(\mathrm{~m}, 3 \mathrm{H}), 7.20-7.17(\mathrm{~m}$, $3 \mathrm{H}), 7.15(\mathrm{t}, J=5.3 \mathrm{~Hz}, 1 \mathrm{H}), 6.92(\mathrm{~m}, 2 \mathrm{H}), 6.84(\mathrm{~m}, 1 \mathrm{H}), 6.67(\mathrm{~d}, J$ $=7.2 \mathrm{~Hz}, 1 \mathrm{H}), 6.26(\mathrm{~d}, J=7.9 \mathrm{~Hz}, 1 \mathrm{H}), 4.13(\mathrm{~d}, J=19.9 \mathrm{~Hz}, 1 \mathrm{H})$, $3.94(\mathrm{~d}, J=19.3 \mathrm{~Hz}, 1 \mathrm{H}), 1.66$ (s, 15H, Cp*). ${ }^{13} \mathrm{C}\left\{{ }^{1} \mathrm{H}\right\}$ NMR: $\delta 182.1,154.1,150.3,147.0,146.9,138.0,136.9,135.1,132.4$, $131.6,128.3,127.5,127.1,126.2$, 123.7, 122.7, 119.8, 117.4, 114.7, 93.9, 91.3, 48.6, 9.0. Anal. calcd for $\mathrm{C}_{36} \mathrm{H}_{32} \mathrm{Br}_{2} \mathrm{IrN}$ : C, 52.05; H, 3.88. Found: C, 51.79; H, 4.03.

9, reaction time $25 \mathrm{~min}$, room temperature, brown crystals (28\% yield). ${ }^{1} \mathrm{H}$ NMR (400 MHz, $\left.\mathrm{CDCl}_{3}\right) \delta 7.89(\mathrm{~d}, J=7.5 \mathrm{~Hz}, 2 \mathrm{H})$, $7.72-7.65(\mathrm{~m}, 11 \mathrm{H}), 7.60(\mathrm{t}, J=7.4 \mathrm{~Hz}, 1 \mathrm{H}), 7.49(\mathrm{~s}, 4 \mathrm{H}), 7.44(\mathrm{t}, J$ $=8.0 \mathrm{~Hz}, 3 \mathrm{H}), 7.30(\mathrm{~d}, J=7.8 \mathrm{~Hz}, 1 \mathrm{H}), 7.24-7.16(\mathrm{~m}, 4 \mathrm{H}), 7.10-$ $6.97(\mathrm{~m}, 4 \mathrm{H}), 6.82(\mathrm{~d}, J=8.0 \mathrm{~Hz}, 1 \mathrm{H}), 4.27(\mathrm{~s}, 1 \mathrm{H}), 1.16(\mathrm{~s}, 15 \mathrm{H}$, Cp*). Anal. calcd for $\mathrm{C}_{69} \mathrm{H}_{47} \mathrm{BF}_{24}$ IrNO: C, 52.95; H, 3.03. Found: C, 52.76; H, 2.92.

\section{Crystallography}

Single crystals of complexes 3, 4c, 5a, 6c, 7, 8b, and 9 (CCDC reference numbers 1589484-1589490†) suitable for X-ray diffraction were obtained by crystallization from $n$-hexane/ $\mathrm{CH}_{2} \mathrm{Cl}_{2}$ (1:1). Data collection was performed on an Oxford Diffraction SuperNova diffractometer, processed with CrysalisPro, and processed with Olex2, using ShelXT as the solution program and refined with SheLX-2014/7, or on a Bruker SMART 
1000, using graphite-monochromated Mo $\mathrm{K} \alpha$ radiation $(\omega-2 \theta$ scans, $\lambda=0.71073 \AA$ ). The crystal data and summary of X-ray data collection are presented in Tables S1 and S2 in the ESI. $\dagger$

\section{Conflicts of interest}

There are no conflicts to declare.

\section{Acknowledgements}

We gratefully acknowledge financial support from the National Natural Science Foundation of China (21572160), and the Program for Innovative Research Team in University of Tianjin (TD12-5038).

\section{Notes and references}

1 (a) J. M. Villar, J. Suárez, J. A. Varela and C. Saá, Org. Lett., 2017, 21, 1702-1705; (b) D. Ghorai, C. Dutta and J. Choudhury, ACS Catal., 2016, 6, 709-713; (c) W. Zhang, C.-Q. Wang, H. Lin, L. Dong and Y.-J. Xu, Chem.-Eur. J., 2016, 22, 907-910; (d) Y.-X. Lao, S.-S. Zhang, X.-G. Liu, C.-Y. Jiang, J.-Q. Wu, Q. Li, Z.-S. Huang and H. Wang, Adv. Synth. Catal., 2016, 358, 2186-2191; (e) C.-Q. Wang, W. Zhang, H. Lin, F. Su and L. Dong, Heterocycles, 2016, 92, 1674-1686; (f) D. L. Davies, C. E. Ellul, S. A. Macgregor, C. L. McMullin and K. Singh, J. Am. Chem. Soc., 2015, 137, 9659-9669; $(g)$ R. Morioka, K. Nobushige, T. Satoh, K. Hirano and M. Miura, Org. Lett., 2015, 17, 3130-3133; (h) Z. Qi, S. Yu and X. Li, J. Org. Chem., 2015, 80, 34713479; (i) D. Ghorai and J. Choudhury, Chem. Commun., 2014, 50, 15159-15162; (j) W. Han, G. Zhang, G. Li and H. Huang, Org. Lett., 2014, 16, 3532-3535; (k) A. G. Algarra, W. B. Cross, D. L. Davies, Q. Khamker, S. A. Macgregor, C. L. McMullin and K. Singh, J. Org. Chem., 2014, 79, 19541970; (l) X.-C. Huang, X.-H. Yang, R.-J. Song and J.-H. Li, J. Org. Chem., 2014, 79, 1025-1031; (m) C. Ma, C. Ai, Z. Li, B. Li, H. Song, S. Xu and B. Wang, Organometallics, 2014, 33, 5164-5172; (n) G. Zhang, L. Yang, Y. Wang, Y. Xie and H. Huang, J. Am. Chem. Soc., 2013, 135, 8850-8853; (o) C.-Z. Luo, P. Gandeepan, J. Jayakumar, K. Parthasarathy, Y.-W. Chang and C.-H. Cheng, Chem.-Eur. J., 2013, 19, 14181-14186; (p) T. Fukutani, N. Umeda, K. Hirano, T. Satoh and M. Miura, Chem. Commun., 2009, 5141-5143.

2 (a) K. J. T. Car, D. L. Davies, S. A. Macgregor, K. Singh and B. Villa-Marcos, Chem. Sci., 2014, 5, 2340-2346; (b) Y. Boutadla, D. L. Davies, R. C. Jones and K. Singh, Chem.Eur. J., 2011, 17, 3438-3448; (c) Y. Boutadla, O. Al-Duaij, D. L. Davies, G. A. Griffith and K. Singh, Organometallics, 2009, 28, 433-440; (d) D. L. Davies, S. M. A. Donald, O. AlDuaij, J. Fawcett, C. Little and S. A. Macgregor, Organometallics, 2006, 25, 5976-5978; (e) D. L. Davies, O. Al-Duaij, J. Fawcett, M. Giardiello, S. T. Hilton and D. R. Russell, Dalton Trans., 2003, 4132-4138.

3 (a) A. P. Walsh and W. D. Jones, Organometallics, 2015, 34, 3400-3407; (b) L. Li, W. W. Brennessel and W. D. Jones, Organometallics, 2009, 28, 3492-3500.
4 (a) L. Barloy, J.-I. Issenhuth, M. G. Weaver, N. Pannetier, C. Sirlin and M. Pfeffer, Organometallics, 2011, 30, 11681174; (b) R. M. Haak, F. Berthiol, T. Jerphagnon, A. J. A. Gayet, C. Tarabiono, C. P. Postema, V. Ritleng, M. Pfeffer, D. B. Janssen, A. J. Minnaard, B. L. Feringa and J. G. de Vries, J. Am. Chem. Soc., 2008, 130, 13508-13509; (c) C. Scheeren, F. Maasarani, A. Hijazi, J.-P. Djukic, M. Pfeffer, S. D. Zarić, X.-F. Le Goff and L. Ricard, Organometallics, 2007, 26, 3336-3345.

5 (a) Y. Kashiwame, S. Kuwata and T. Ikariya, Chem.-Eur. J., 2010, 16, 766-770; (b) S. Arita, T. Koike, Y. Kayaki and T. Ikariya, Organometallics, 2008, 27, 2795-2802.

6 M. E. Tauchert, C. D. Incarvito, A. L. Rheingold, R. G. Bergman and J. A. Ellman, J. Am. Chem. Soc., 2012, 134, 1482-1485.

7 (a) B.-B. Guo, Y.-J. Lin and G.-X. Jin, Dalton Trans., 2017, 46, 8190-8197; (b) L. Lin, Y.-Y. Zhang, Y.-J. Lin and G.-X. Jin, Dalton Trans., 2016, 45, 7014-7021; (c) Y.-F. Han and G.-X. Jin, Chem. Soc. Rev., 2014, 43, 2799-2823; (d) Y.-F. Han, H. Li, P. Hu and G.-X. Jin, Organometallics, 2011, 30, 905-911; (e) Y.-F. Han, H. Li, L.-H. Weng and G.-X. Jin, Chem. Commun., 2010, 46, 3556-3558.

8 L. S. Park-Gehrke, J. Freudenthal, W. Kaminsky, A. G. DiPasquale and J. M. Mayer, Dalton Trans., 2009, 1972-1983.

9 W. Bauer, M. Prem, K. Polborn, K. Sünkel, W. Steglich and W. Beck, Eur. J. Inorg. Chem., 1998, 485-493.

10 (a) Y. Ikeda, S. Kodama, N. Tsuchida and Y. Ishii, Dalton Trans., 2015, 44, 17448-17452; (b) M. F. Espada, M. L. Poveda and E. Carmona, Organometallics, 2014, 33, 7164-7175; (c) Y. Boutadla, D. L. Davies, O. Al-Duaij, J. Fawcett, R. C. Jones and K. Singh, Dalton Trans., 2010, 39, 10447-10457; (d) L. Li, Y. Jiao, W. W. Brennessel and W. D. Jones, Organometallics, 2010, 29, 4593-4605; (e) D. L. Davies, O. Al-Duaij, J. Fawcett and K. Singh, Organometallics, 2010, 29, 1413-1420; $(f)$ L. Li, W. W. Brennessel and W. D. Jones, J. Am. Chem. Soc., 2008, 130, 12414-12419.

11 A. Savini, G. Bellachioma, G. Ciancaleoni, C. Zuccaccia, D. Zuccaccia and A. Macchioni, Chem. Commun., 2010, 46, 9218-9219.

12 R. Sun, S. Zhang, X. Chu and B. Zhu, Organometallics, 2017, 36, 1133-1141.

13 (a) F. E. Fernández, M. C. Puerta and P. Valerga, Inorg. Chem., 2013, 52, 6502-6509; (b) Y. Mutoh, K. Imai, Y. Kimura, Y. Ikeda and Y. Ishii, Organometallics, 2011, 30, 204-207; (c) V. K. Singh, E. Bustelo, I. de los Ríos, I. Macías-Arce, M. C. Puerta, P. Valerga, M. A. Ortuño, G. Ujaque and A. Lledós, Organometallics, 2011, 30, 4014-4031; (d) E. Bustelo, I. de los Ríos, M. C. Puerta and P. Valerga, Organometallics, 2010, 29, 1740-1749; (e) M. J. Shaw, S. W. Bryant and N. Rath, Eur. J. Inorg. Chem., 2007, 39433946.

14 Á. M. Martínez, J. Echavarren, I. Alonso, N. Rodríguez, R. G. Arrayás and J. C. Carretero, Chem. Sci., 2015, 6, 58025814.

15 R. L. Sahani and R.-S. Liu, Angew. Chem., Int. Ed., 2017, 56, 12736-12740. 